\title{
Detection of adulteration of Decalepis hamiltonii Wight \& Arn. with Hemidesmus indicus (L.) R. Br. by pharmacognostic, molecular DNA fingerprinting by RAPD, chemical and HPTLC studies
}

\author{
Sujith $\mathrm{T}^{1}$, Susikumar $\mathrm{S}^{2,}$ Sunilkumar $\mathrm{KN}^{2}$, Radha $\mathrm{P}^{3}$, Shakila $\mathrm{R}^{1^{*}}$ \& Gopinath $\mathrm{P}^{4^{*}}$ \\ ${ }^{1}$ Department of Chemistry, ${ }^{2}$ Department of Pharmacognosy, Siddha Central Research Institute (Central Council for Research in Siddha, \\ Ministry of AYUSH), Anna Hospital Campus, Arumbakkam, Chennai 600 106, Tamil Nadu, India \\ ${ }^{3}$ Siddha Medicinal Plants Garden (Central Council for Research in Siddha, Ministry of AYUSH), Mettur 636 401, Tamil Nadu, India \\ ${ }^{4}$ Department of Chemistry, SRM Institute of Science and Technology, Kattankulathur, Chennai 603 203, Tamil Nadu, India \\ *Email: gopinatp1@srmist.edu.in | r.shakila@gov.in
}

\section{ARTICLE HISTORY}

Received: 02 March 2021

Accepted: 28 May 2021

Available online: 01 July 2021

\section{KEYWORDS}

Decalepis hamiltonii

Hemidesmus indicus

Adulteration

Substitution

Molecular DNA finger printing

RAPD

\section{ABSTRACT}

Hemidesmus indicus (L.) R. Br. (Apocynaceae) root is extensively used in Indian traditional systems due to its biological activities. Decalepis hemiltonii Wight \& Arn. is another member from the same family resembling $\mathrm{H}$. indicus and is adulterated in the herbal market. Aim of the study was to compare and evaluate the distinguishing features based on macroscopy, microscopy, powder microscopy, molecular differences in the genomic DNA by RAPD, physiochemical, phytochemical screening, TLC and HPTLC fingerprint profiling of successive extracts. Microscopically cork, cortex, phloem, xylem, medullary rays and pith; powder microscopically size and shape of the cork cells, fibre, fibre tracheids, vessels, xylem parenchyma cells were different from each other. Polymorphism $(75.4 \%)$ was found in eight primers out of 16 primers analyzed. The water soluble extractive and the hexane soluble extractive of $D$. hamiltonii was higher than $\mathrm{H}$. indicus. Tannins, flavonoids, steroids and coumarins were present only in $H$. indicus and absent in $D$. hamiltonii. After derivatization, spots at $R_{f} 0.88$ (hexane extract), 0.81 (chloroform extract) and 0.55 (ethanol extract) in $\mathrm{H}$. indicus; spots at $\mathrm{R}_{\mathrm{f}} 0.22,0.45$ (chloroform extract), $0.19,0.35,0.58,0.59$ (ethanol extract) in $D$. hamiltonii were observed. This study will be helpful to find out adulteration of $\mathrm{D}$. hemiltonii in place of $\mathrm{H}$. indicus sold in the crude drug market and in herbal formulations.

\section{Introduction}

Plants have been the basis of many traditional medicines throughout the world for thousands of years due to their therapeutic efficacy. It is estimated that herbal medicine in developed countries make up to one fourth; while in developing countries it is up to three fourth of all medicines (1). The use of herbal drugs is rapidly increasing worldwide as the herbal drugs were found to be beneficial in treating mild to moderate diseases in all age groups and in averting illnesses thereby promoting health (2). Roots of $H$. indicus is an important plant drug used as a tonic, demulcent, diaphoretic and diuretic as per Siddha literature, it is used to treat a variety of diseases such as leprosy, leucoderma, itching, skin disease, body coolant, asthma, bronchitis, leucorrhoea, dysentery, piles, syphilis, paralysis, urinary disorders and diabetes (3). Hemidesmus indicus (L.) R. Br. is commonly known as Indian sarsaparilla, False sarsaparilla in English; Anantamul, Hindisalsa in
Hindi; Anantumula, sariva, Dhavalasariva, Krishodari, Nagajihva, Sugandha in Sanskrit; Salsa in Urdu; Upalsan in Marathi; Nannari in Tamil; Narunenti in Malayalam; Sugandhi pala in Telugu; Namdaberu, Sogada beru in Kannada; Onontomulo, Suguddimalo in Oriya; Upalasari, Sariva, Anantvel in Gujarati; Anantamul in Manipuri and Ushba in Persian (4). It is used in in Siddha formulations viz., Carapunka vilvati ilakam, Ilaku cantanatit tailam, Pitta curak kutinir (5), Kumari ilakam, senkathari ennai, Sowbakkiya sundi ilakam, Thippili nei, Pericchangai nei, Maha vilvathi ilakam (6); root bark in Manturati attaik kutinir, Parankip pattai iracayanam (5), Nannari manapagu, Pancha paadana chenduram (7); in Sarivadyasava an Ayurvedic formulation (8). Due to these, $H$. indicus has high demand in traditional medicine system and herbal drug industries. At the same time availability of this plant is decreasing and the cultivation is also less to meet out the commercial demand. This gap is being utilized by crude drug collectors, suppliers and sellers to adulterate similar looking plant species. 
Decalepis hamiltonii Wight \& Arn. is commonly known as Maredu kommulu, Nannari kommulu, Barre Sugandhi; Swallow root in English; Sariba, Sveta sariva in Sanskrit; Makaliber in Kannada; Magali kizhangu, Peru nannari, Mavilinga kilangu in Tamil; Madina kommulu, Maredu gaddalu in Telugu; Nannari in Malayalam (9) but not found medicinal value like $H$. indicus.

Hemidesmus indicus possesses anti-asthmatic activity (10), diuretic and anti-urolithiatic activity (11), nephroprotective activity (12) and neuroprotective activity (13), D. hamiltonii exhibits anti-inflammatory activity (14), neuroprotective activity (15) and hepatoprotective activity (16).

Both plant roots contain 2-hydroxy 4-methoxy benzaldehyde as major compound (17), lupeol, aamyrin, $\beta$-amyrin, lupeol acetate, $\alpha$-amyrin acetate, $\beta$ amyrin acetate (18-20) reported from various extracts of the root. However, in specific, $H$. indicus contains hemidesminine (21), hemidesmin-1, hemidesmin-2 (22), hemidesmol, hemidesterol (23) and D. hamiltonii

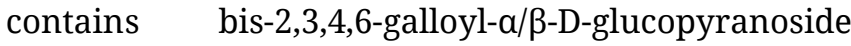
(decalepin) (24).

$D$. hamiltonii root is often adulterated with $H$. indicus because of the common availability in South India and bigger in size. Variety of adverse reactions due to adulteration are caused ranging from minor (allergic reactions, tiredness, digestive disorder, temper distraction or muscle weakness, nausea and breathing problems) to medium (misperception, fits, dermatitis, sensory disorders) and severe life threatening effects (cancer, cerebral oedema, unconsciousness, intracerebral haemorrhage, poisoning, metabolic acidosis, multi-organ failure, perinatal stroke, renal or liver failure or death) (25).

There are two reports published in 2017 by World Health Organization (WHO) on the investigation of inferior and fabricated medicines and their influence (26). The ancient Ayurvedic literature, Charaka Samhita indicates that medicines (Ayurvedic) have undesirable effects if they are not appropriately prepared or used wrongly (27). However, Indian traditional herbal medicines of Ayurveda, Siddha and Unani (ASU) origin are whispered harmless because of their long time use. According to the Drugs and Cosmetics Act of 1940 (DCA), no safety and efficacy studies are required for marketing approval for ASU drugs (28). At the same time, for trademarked herbal drugs, ethnomedicinal use based drugs and extract based drugs, safety and efficacy studies are mandatory (29). The crucial benchmark for substitution should be the pharmacological activity than the morphology or phytochemicals of the plant drug (30).

For the detection of adulterants, different techniques, viz., thin layer chromatography (TLC), high performance thin layer chromatography (HPTLC), high-performance liquid chromatography (HPLC), high-resolution melting (HRM), liquid chromatography-mass spectrometry (LCMS), nuclear magnetic resonance (NMR), polymerase chain reaction-restriction fragment length polymorphism (PCR-RFLP), random amplified polymorphic DNA (RAPD), sequence characterised amplified region
(SCAR), single nucleotide polymorphism (SNP) etc. are available for different plants (31). Near-infrared (NIR), infrared (IR), Raman, liquid chromatographycircular dichroism (LC-CD), liquid chromatographymass spectrometry (LC-MS), thin layer chromatography-surface enhanced Raman spectroscopy (TLC-SERS) and thin layer chromatography-mass spectrometry (TLC-MS) (32). But depending on the facilities, comparatively cheaper and easier technique is adapted for detection of adulteration. Plants from different genera, families, species, cultivars (cultivated variety) and sibling plants can be distinguished by DNA fingerprinting method (33). Sequence characteristic amplified region (SCAR) marker which is an advanced technique, RAPD finger prints and MALDITOF were developed for $H$. indicus by earlier researchers (34). In the present study, authors have selected different primers for RAPD analysis (35). Pharmacopoeial parameters such as macroscopy, microscopy, powder microscopy, physiochemical, TLC identification along with HPTLC finger printing have been carried out for both samples.

\section{Materials and Methods \\ Collection of Samples}

Root samples of $H$. indicus were collected from Palayamkottai, Tirunelveli district, Tamil Nadu during the month of January 2019 and $D$. hemiltonii were collected from Salem district, Tamil Nadu, India authenticated by the Pharmacognosist of this Institute.

\section{Macroscopy, Microscopy \& Powder Microscopy}

The macro-morphological study was carried out by following the standard methods (36-38). The anatomical studies were carried by following standard procedures (38-40). For powder microscopic study the plant material after cleaning, dried properly, powdered and passed through sieve No. 80 . The mounting and staining was carried out by standard methods (40-41). Photograph of sections and powder were made under different magnifications with the help of Olympus BX51 microscope fitted with Olympus camera.

\section{Genomic DNA Isolation}

The genomic DNA was extracted by modified cetyl trimethyl ammonium bromide (CTAB) method (42).

\section{Purification of DNA}

The silica membrane based column (Qiagen) was placed in collection tube, $400 \mu \mathrm{l}$ of equilibrium buffer was added to the column and centrifuged at $10000 \mathrm{rpm}$ for $1 \mathrm{~min}$. Collected buffer was discarded. $400 \mu \mathrm{l}$ of equilibrium buffer was added to the DNA samples, mixed and loaded into the column (This step was repeated till the DNA sample was completed). Break through was collected. $500 \mu \mathrm{l}$ of vanadium salt in alcohol high concentration (wash buffer 1) was added, centrifuged at $10000 \mathrm{rpm}$ for 1 min and buffer was collected. $500 \mu \mathrm{l}$ of vanadium salt in alcohol low concentration (wash buffer 2) was added, centrifuged at $10000 \mathrm{rpm}$ for $1 \mathrm{~min}$ and 
buffer was collected. The column was centrifuged with empty collection tube to completely remove the wash buffer for $2 \mathrm{~min}$. $50 \mu \mathrm{l}$ of tris-EDTA buffer (elution buffer) was added to the column placed in new collection tube. Incubated at room temperature for two min and centrifuged at $10000 \mathrm{rpm}$ for one min and eluted sample was saved (elution 1). Previous step was repeated (DNA may elute in this fraction also) (eluted sample was saved as elution 2) Quantization of eluted DNA samples was done by loading into the Agarose gel.

\section{RAPD Analysis}

Genomic DNA polymorphism was determined by Random Amplified Polymorphic DNA (RAPD) method (43). Amplification reactions were carried out in a total volume of $40 \mu \mathrm{l}$ PCR reaction containing $200 \mathrm{ng}$ genomic DNA, $4 \mu \mathrm{l} 1 \mathrm{X}$ reaction buffer, $20 \mu \mathrm{l}$ of $2 \mathrm{X}$ PCR master mix, $1 \mu \mathrm{l}$ of standard arbitrary decamer oligonucleotides (Operon Technologies Inc. USA) and $17 \mu$ l of distilled water. Total of 16 primer sets were used. Amplification products were separated on 1.5 or $2 \%$ agarose gel in tris-borate-EDTA buffer (TBE buffer) and stained with ethidium bromide and visualized in the UV light.

DNA amplification was performed in the thermal cycler (Eppendroff, Hamberg, Germany) programed for 42 cycles as follows: the first step consisted of holding the sample at $94{ }^{\circ} \mathrm{C}$ for $5 \mathrm{~min}$ for complete denaturation of template DNA. The second step comprise of 40 cycles and each cycle comprise of three temperature steps i.e. $30 \mathrm{~s}$ at $94{ }^{\circ} \mathrm{C}$, for denaturation of template, one min at $45{ }^{\circ} \mathrm{C}$ primer annealing followed by $1 \mathrm{~min}$ and $30 \mathrm{~s}$ at $72{ }^{\circ} \mathrm{C}$ for primer extension. The third step comprise of only one cycle i.e. $5 \mathrm{~min}$ at $72{ }^{\circ} \mathrm{C}$ for complete polymerization followed by holding at $4{ }^{\circ} \mathrm{C}$. After completion of PCR, amplified products were stored at $-20{ }^{\circ} \mathrm{C}$ for further use.

\section{Data Analysis}

The RAPD-PCR bands were scored as ' 1 ' for the presence and ' 0 ' for absence (44). From the Genetic similarity data among accession between the two samples were determined with respect to the similarity (dissimilarity) index method calculated using the Jaccard's similarity coefficient. Distances between individuals were calculated by clustering analysis (nearest neighbour method) with the help of the StatistiXL program (version 2) (45).

\section{Chemicals, Solvents and Reagents}

All the chemicals and solvents used were AR grade (Merck). For visualizing the developed spots in TLC, reagent containing vanillin (1 gm) sulphuric acid (5\%) in ethanol (VSA) was used.

\section{Instrument for HPTLC}

For HPTLC, aluminium plate (Merck) pre coated with Silica gel $60 \mathrm{~F}_{254}$ of $0.2 \mathrm{~mm}$ thickness was used. Automatic sampler ATS4 for application on TLC plate, twin trough chamber $(10 \times 10 \mathrm{~cm})$ for plate development, visualizer for photo documentation under UV-visible conditions, Scanner 4 with winCATS software for finger prints, TLC plate heater for derivatization (all from CAMAG, Switzerland).

\section{Physico-Chemical Parameters}

All the physiochemical parameters for D. hamiltonii Wight \& Arn. and $H$. indicus (L.) R. Br. were carried out as per standard methods (46).

\section{Phytochemical Screening}

The phytochemical tests for phenol, tannin, flavonoids, triterpenoids, proteins, glycosides, reducing sugar, anthraquinones, quinones, alkaloids, saponins, cardiac glycoside, steroids, coumarins and acids were done by using the standard methods (47).

\section{Preparation of Extracts}

Powdered root samples of $D$. hamiltonii and $H$. indicus (25 gm) were extracted successively with nhexane, chloroform and ethanol using Soxhlet apparatus for $6 \mathrm{hrs}$. Concentrated and dried and the corresponding weights were recorded for calculating the yield as successive extractive values. The extract residue were re-dissolved in corresponding solvents and sonicated for ten minutes then filtered and made up to $2 \mathrm{ml}$ and transferred into sample vials for TLC application.

\section{Mobile Phases}

The mobile phase for n-hexane extract, hexane:ethyl acetate (8:0.5, v/v); for successive chloroform, toluene:ethyl acetate:formic acid (10:2:0.2, v/v/v); for successive ethanol, toluene:ethyl acetate: methanol $(8: 2: 0.7, \mathrm{v} / \mathrm{v} / \mathrm{v})$ were finalized.

\section{TLC/HPTLC Procedure}

Hexane $(10 \mu \mathrm{l})$, chloroform $(20 \mu \mathrm{l})$ and ethanol $(10 \mu \mathrm{l})$ extracts in 3 different plates $(8 \times 10 \mathrm{~cm})$ as $8 \mathrm{~mm}$ bands was applied on silica gel $60 \mathrm{~F}_{254}$ coated aluminium plate using ATS4 applicator from $10 \mathrm{~mm}$ from left side and $10 \mathrm{~mm}$ from bottom of the plate The plates were developed in the respective mobile phases in presaturated twin trough chamber $(10 \times 10$ $\mathrm{cm})$. The plates were developed up to $90 \mathrm{~mm}$ from the bottom. The developed plates were air dried, viewed under UV $254 \mathrm{~nm}, 366 \mathrm{~nm}$ and the images were documented using Visualizer followed by dual wavelength scanning using Scanner 4 at $\lambda 254 \mathrm{~nm}\left(\mathrm{D}_{2}\right.$ lamp/absorption mode) and $\lambda 366 \mathrm{~nm}$ (Hg lamp/fluorescence mode) with a slit dimension of $6 \times 0.45 \mathrm{~mm}$ and scanning speed of $20 \mathrm{~mm} / \mathrm{s}$. Then, the TLC plates were dipped in a dip tank containing VSA reagent and heated at $100{ }^{\circ} \mathrm{C}$ or till the appearance of coloured spots. Immediately the derivatized TLC plates were photo documented at white light followed by scanning at $\lambda 520$ (W lamp/absorption mode) for finger prints.

\section{Results and Discussion}

\section{Macroscopy, Microscopy and Powder Microscopy}

The detailed macroscopic (Supplementary Table 1; Supplementary Fig 1 \& 2), microscopic (Table 1) and powder microscopic characters (Table 2) are reported. The problem arises literally from the market samples in the name of Nannari, Actually, in Siddha, Nannari botanically equated $H$. indicus (L.) R. Br. ex Schult. and Malai nannari is referred as D. hamiltonii Wight \& Arn. Macroscopically size, 
Table 1. Microscopic characters of $D$. hamiltonii and $H$. indicus

Characters Decalepis hamiltonii (48)

Brown colored narrow cork followed by off-white wide zone of cortex and phloem having centrally located porous xylem (Fig 3A).

Different layers of cells, occurring one after the other, such as; wavy, thick walled, compressed, suberized, rectangular, tangentially elongated, 5 to 10 exfoliating rows of cell layers filled with reddish brown content; 4 to 8 rows of thin walled non-suberized cells rows; 5 to 10 rows of compressed, rectangular and a few polygonal, suberized cork filled with brownish content (Fig. $4 \mathrm{~A})$.

\begin{tabular}{ll}
\hline Phellogen & Distinct colorless 1 or 2 row cells. \\
\hline Phelloderm & $\begin{array}{l}\text { Narrow zone of compressed, thin and thick } \\
\text { walled cells. }\end{array}$ \\
\hline
\end{tabular}

Cortex

Wide zone of thin walled parenchymatous cells showing presence of a few sclereids, prismatic crystals, latexcanalsand starch grains.
Hemidesmus indicus (48-51)

Narrow cork, cortex, phloem and wide zone of central core xylem (Fig 3B); Root stock shows narrow cork, cortex, phloem and central parenchymatous pith encircled by wide zone of xylem (Fig 3C).

Different layers of tissues such as compressed, thick walled, suberized, rectangular, tangentially elongated, 5 to 25 cells rows of exfoliating, narrow band of cells filled with reddish or purplish brown color content (Fig. 4B \& 4C).

Distinct colorless1 or 2 row cells.

Compressed 4 to 16 rows of cells containing brownish content (tannin) and prismatic crystals of calcium oxalate.

Wide zone of thin walled, polygonal, parenchymatous cells with abundant round to oval, helmet shaped, simple and mult component starch grains with hillum; non-articulated laticiferous canals, cavities, brownish content, oil globules and prismatic crystals; rarely a few sclereids between phelloderm and cortex regions in roots above $1 \mathrm{~cm}$ thickness.

Narrow zone of phloem cells consisting of sieve elements, thin walled tangentially elongated, larger towards periphery and become smaller compressed rectangular cells towards inner side; ceratenchyma, laticiferous cells, a few starch grains and prismatic crystals are found distributed in the region; in root stock pith region contain groups of primary inner phloem consisting of compressed collapsed cells, without any cell content and fibres.

Various sized, round to oval, mostly single or 2 or 3 grouped diffused porous vessels,a few showingtylosis; thick walled wide lumen fibre and fibretracheids; thin walled uni-seriate xylem ray cells and thick-walled axial parenchyma cells embedded with a few starch grains, oil globule and prismatic crystals.

Very wide zone of xylem consist variously sized, round to oval, mostly single or 2 or 3 grouped, diffused porous vessels showing a few tylosis and resin like brownish content; thick walled xylem fibres with wide lumen; thick walled xylem axial parenchyma parenchyma containing a few starch grains, oil globules and prismatic crystals of calcium oxalate.

Phloem rays uni-seriate, cells being larger in size than that of other phloem cells; mostly uni-seriate xylem rays, rarely bi and tri-seriate with a few starch grains, oil globules and prismatic crystals of calcium oxalate

Centrally located protoxylem in root; thin walled parenchymatous cells embedded with abundant starch grains, a few laticiferous cells, prismatic crystals in root stock. external morphology, color, odour, taste are different and microscopically (Fig. 1-2) cork, cortex, phloem, xylem, medullary rays and pith characters are different from each other. Depending upon thickness of the root and root stock, place of stone cells, sclereids and fibres may be present or absent. Powder microscopically size and shape of the cork cells, fibre, fibre tracheids, vessels, xylem parenchyma cells are different (Fig. 3-4).

\section{Molecular DNA fingerprinting by RAPD}

DNA isolation was done by modified CTAB-based protocol and the isolated DNA is shown in Fig. 5. Total DNA extracted is $3 \mu \mathrm{l}$ in which $2 \mu \mathrm{l}$ of sample was used for PCR. Sixteen primers were selected for polymorphism. Out of sixteen primers used, eight primers produced the most polymorphic bands. The list of eight primers are presented (Supplementary Table 2) and the banding pattern of genomic DNA is shown in Fig. 6. The percentage of polymorphism is found to be $75.4 \%$.

The number of different bands developed in molecular DNA fingerprinting by RAPD, play an important role in differentiating the plants (45), especially Primers that successfully amplify DNA showed different patterns. Information on polymorphism of these both plants can be used as a reference for detection of authentic herbal drug. Out of sixteen primers, eight primers showed polymorphic bands and totally sixty one bands appeared in which forty six were polymorphic. In OPH-05 all six bands are polymorphic and this may be suitable one for distinguishing both plants.

\section{Physico-chemical Analysis}

The physico-chemical parameters were carried out in duplicates and the mean values are presented (Supplementary Fig. 3). In the physicochemical point of view, the total ash of $D$. hamiltonii is $10.77 \%$ which is approximately three time more than the total ash value of $H$. indicus (3.69\%). Similarly the acid insoluble ash value of $D$. hamiltonii is $4.07 \%$ and that of $H$. indicus is $0.93 \%$ which means that the siliceous matter adhered on the root of $D$. hamiltonii is high. The water soluble extractive value of $D$. hamiltonii is $20.88 \%$ which is higher than $H$. indicus even in the presence of higher content of siliceous matter. This indicates that $D$. hamiltonii contains more polar compounds than $H$. indicus which are soluble in water. 
Table 2- Powder microscopic characters of $D$. hamiltonii and $H$. indicus

\begin{tabular}{|c|c|c|}
\hline Characters & Decalepis hamiltonii (48) & Hemidesmus indicus (48-51) \\
\hline Cork & $\begin{array}{l}\text { Thin and thick walled suberized cells filled with } \\
\text { brownish content, up to } 150 \mu \text { in length and up to } \\
100 \mu \text { width in surface view (Fig. 5). }\end{array}$ & $\begin{array}{l}\text { Thin walled, suberized cells filled with reddish or } \\
\text { purplish brown color content up to } 100 \mu \text { in length and } \\
\text { up to } 60 \mu \text { width in surface view (Fig. } 6 \text { ). }\end{array}$ \\
\hline $\begin{array}{l}\text { Parenchymatous } \\
\text { cells }\end{array}$ & Thin and thick walled cells & Thin walled cells \\
\hline Sclereids & $\begin{array}{l}\text { Varying in shape, up to } 220 \mu \text { in length and up to } \\
75 \mu \text { in width }\end{array}$ & $\begin{array}{l}\text { Varying in shape, up to } 200 \mu \text { in length and up to } 70 \mu \text { in } \\
\text { width }\end{array}$ \\
\hline Fibres & $\begin{array}{l}\text { Thick walled, wide lumen, sharp ends with a few } \\
\text { fork and pegged, size up to } 750 \mu \text { in length and up } \\
\text { to } 60 \mu \text { in width }\end{array}$ & $\begin{array}{l}\text { Thick walled, wide lumen, sharp and blend ends with a } \\
\text { few pegged out growth, size up to } 750 \mu \text { in length and up } \\
\text { to } 40 \mu \text { in width }\end{array}$ \\
\hline Vessels & $\begin{array}{l}\text { Simple perforated, mostly pitted and a few } \\
\text { bordered pitted. Pitted vessels up to } 650 \mu \text { in } \\
\text { length and up to } 160 \mu \text { in width }\end{array}$ & $\begin{array}{l}\text { Tailed, simple perforated, pitted vessels up to } 400 \mu \text { in } \\
\text { length and up to } 80 \mu \text { in width }\end{array}$ \\
\hline Fibre tracheids & $\begin{array}{l}\text { Varying in shape with numerous simple pits up } \\
\text { to } 900 \mu \text { in length and up to } 60 \mu \text { in width }\end{array}$ & $\begin{array}{l}\text { Thick walled wide lumen, sharp and blend ends with a } \\
\text { few pegged out growth, size up to } 750 \mu \text { in length and up } \\
\text { to } 40 \mu \text { in width }\end{array}$ \\
\hline Xylem parenchyma & $\begin{array}{l}\text { Non lignified, ray parenchymatous up to } 150 \mu \text { in } \\
\text { length and up to } 60 \mu \text { in width; axial parenchyma } \\
\text { up to } 50 \mu \text { in length and up to } 60 \mu \text { in width }\end{array}$ & $\begin{array}{l}\text { Lignified, Ray and axial cells up to } 100 \mu \text { in length and up } \\
\text { to } 40 \mu \text { in width }\end{array}$ \\
\hline Latex canals & $\begin{array}{l}\text { non-articulated, branched, embedded with } \\
\text { prismatic crystals, }\end{array}$ & non-articulated \\
\hline Starch grains & $\begin{array}{l}\text { abundant round to oval, simple and compound } \\
\text { starch grains } 10-30 \mu \text { in size }\end{array}$ & $\begin{array}{l}\text { abundant round to oval, helmet shaped, simple and } \\
\text { multi component with fissure hillum, } 10-40 \mu \text { in size }\end{array}$ \\
\hline Crystals & Prismatic crystals of calcium oxalate & Prismatic crystals of calcium oxalate \\
\hline
\end{tabular}

Fig. 1. Microscopy diagrammatic TS. A. D. hamiltonii root; B. H. indicus root; C. H. indicus root stock.

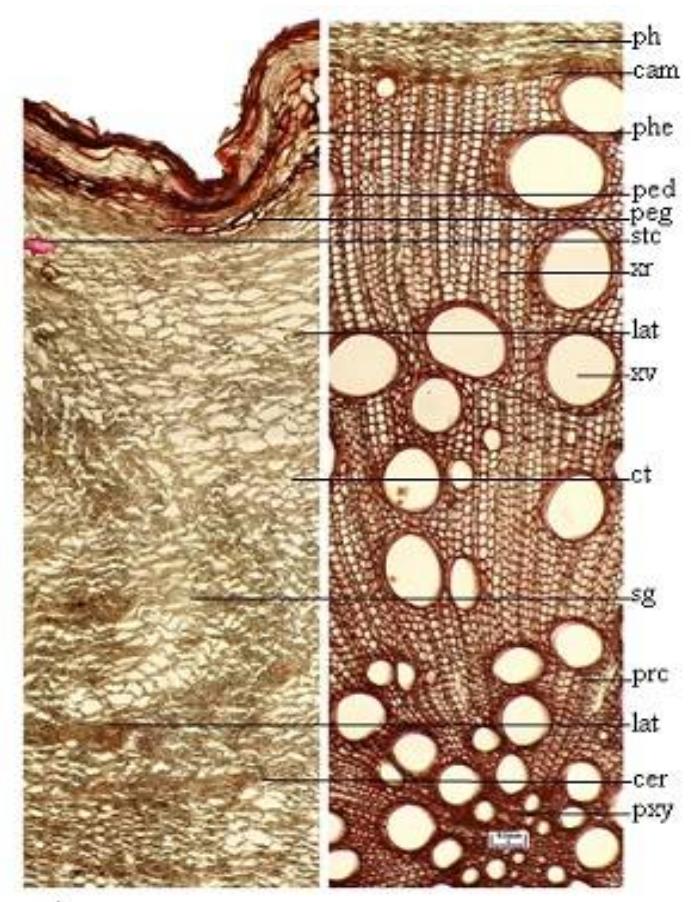

A

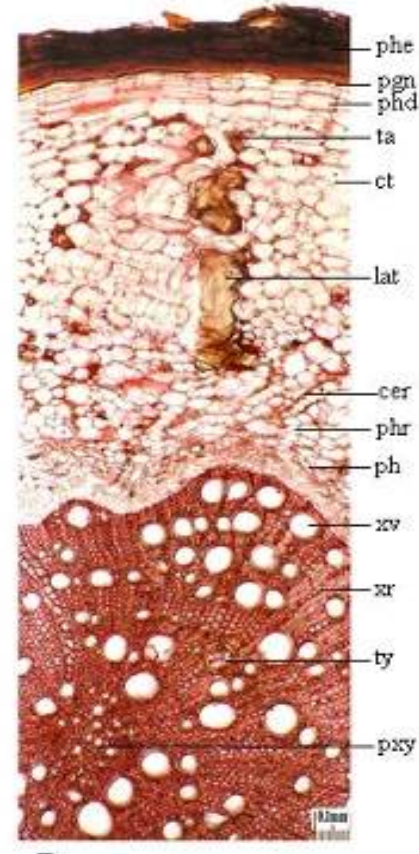

B

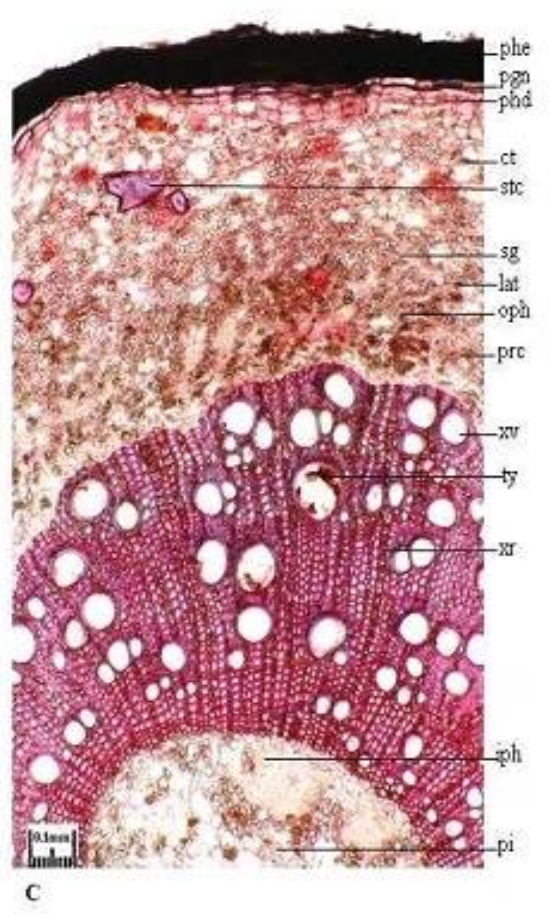

C

Fig. 2. Microscopy detailed TS- A. D. hamiltonii root; B. H. indicus root; C. H. indicus root stock. 

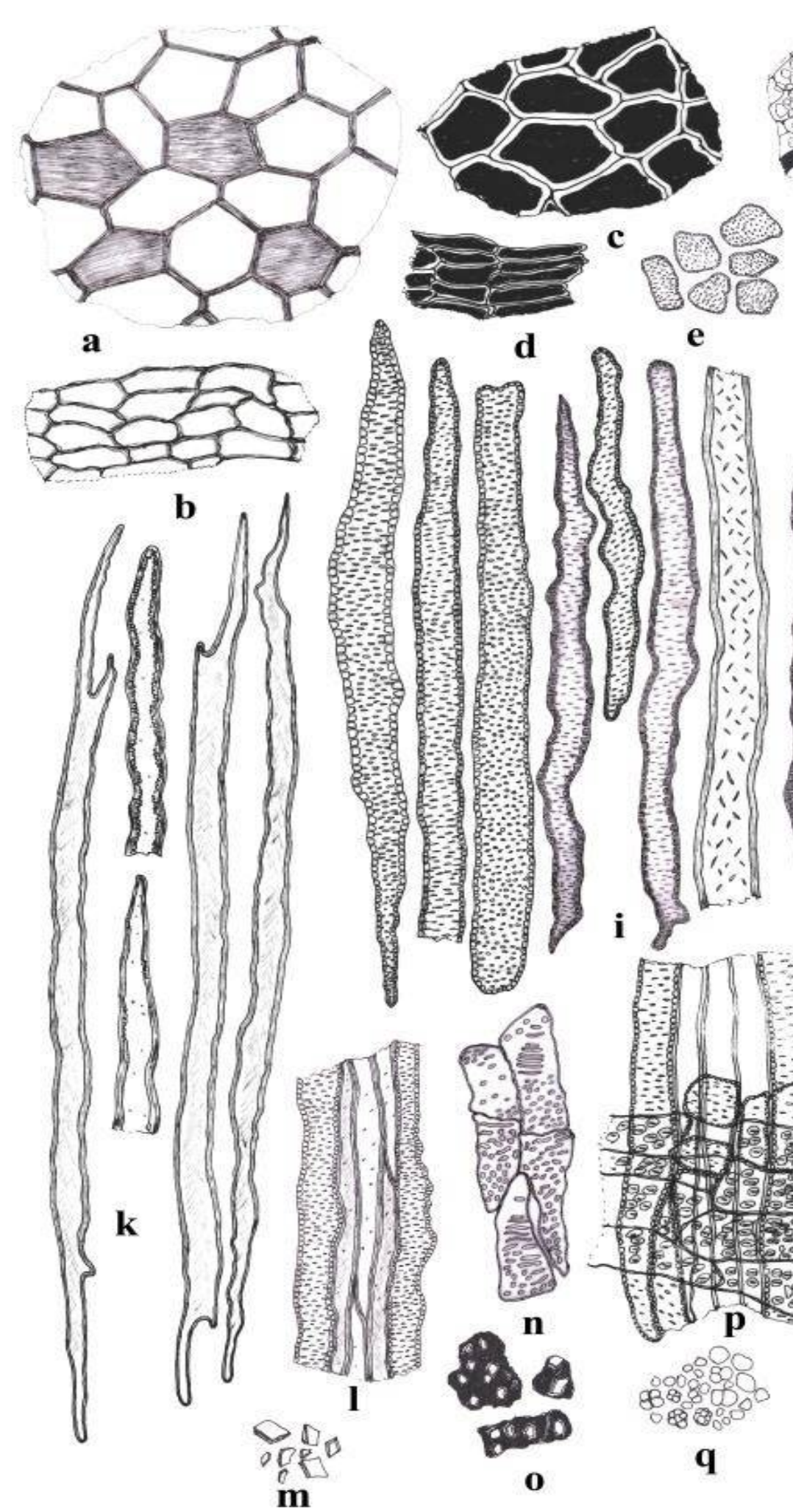

e
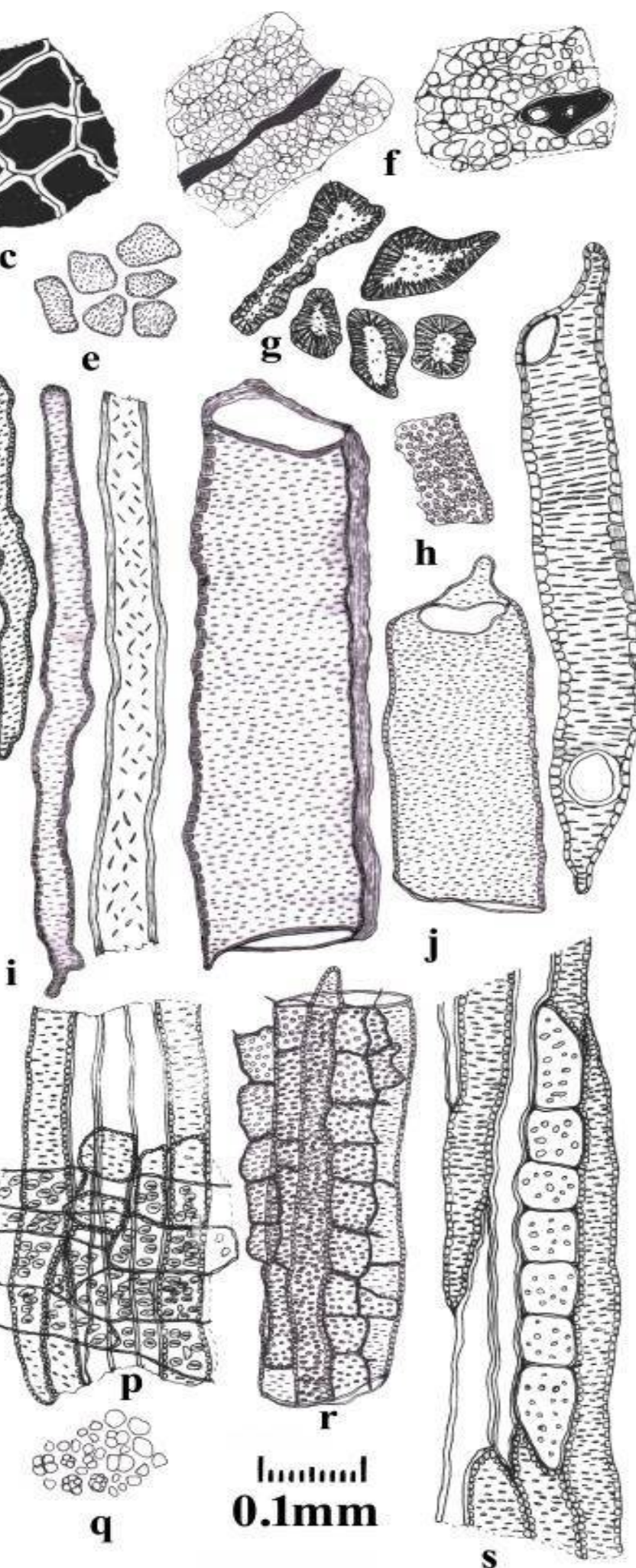

Fig. 3. Powder microscopy of $D$. hamiltonii . a, cork cells in surface view with brownish content; b, cork cells in sectional view; c, suberized cork cells in surface view; d, suberized cork cells in sectional view; e, xylem axial parenchyma cells; f, parenchymatous cells embedded with starch grains and latex canals; $\mathbf{g}$, stone cells; $\mathbf{h}$, bordered pitted vessels; $\mathbf{i}$, fibretracheids; $\mathbf{j}$, pitted vessels; $\mathbf{k}$, fibres; $\mathbf{l}$, fragment of fibre associated with fibretracheids; m, prismatic crystals of calcium oxalate; $\mathbf{n}$, xylem ray parenchymatous cells; $\mathbf{o}$, latex embedded with prismatic crystals; $\mathbf{p}$, radially cut medullary rays crossing with fibre and fibretracheids; q, starch grains; $\mathbf{r}$, tangentially cut vessels and fibre tracheid associated with xylem axial parenchymacells; $\mathbf{s}$, tangential longitudinally cut medullary rays associated with fibre and fibretracheids.

The water and alcohol soluble extractive of $H$. indicus are almost equal. The alcohol soluble extractive value of both species are more or less equal which means that the presence of similar quantity of polar compound which are soluble in organic solvents. The $n$-hexane soluble extractive value of $D$. hamiltonii is $4.37 \%$ and $H$. indicus $2.54 \%$ which is an indication of presence of higher volume of low polar compounds in $D$. hamiltonii than $H$. indicus. With the difference in physicochemical values would facilitate the authentication of drugs (52). In a previous study on D. hamiltonii and $H$. 


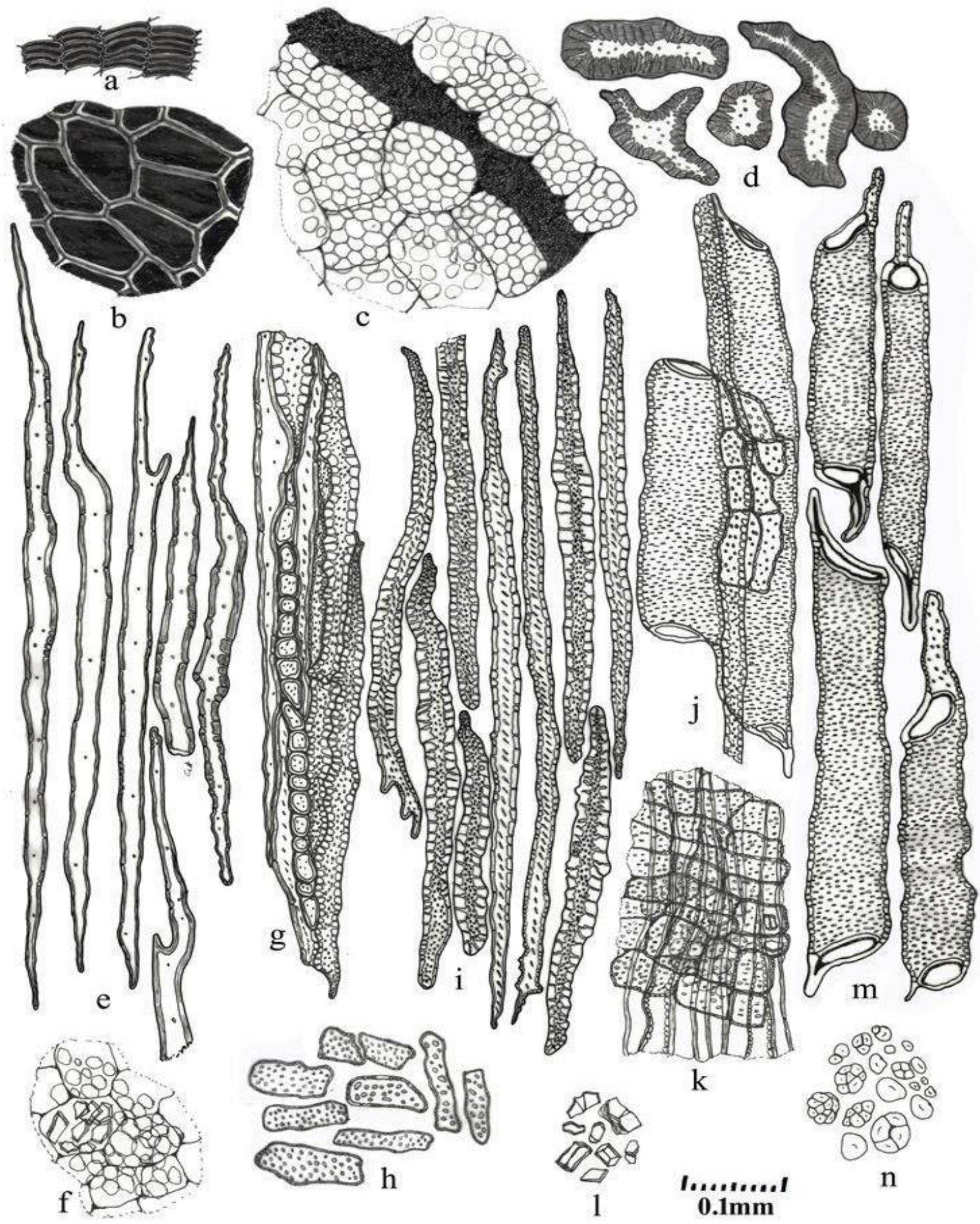

Fig. 4. Powder microscopy of $H$. indicus root and root stock. a. cork cells in sectional view; $\mathbf{b}$. cork cells in surface view; c. fragment of parenchyma cells associated with laticiferous canal; d. stone cells and sclereids; e. thick walled, wide lumen, sharp end fibres; f. parenchymatous cells embedded with starch grains and prismatic crystals of calcium oxalate; g. tangential longitudinally cut xylem ray associated with fibre and fibre tracheids; $\mathbf{h}$. lignified xylem parenchyma; $\mathbf{i}$. thick walled fibre tracheids; $\mathbf{j}$. longitudinally cut fragment of fibre tracheid associated with xylem parenchyma and pitted vessels; $\mathbf{k}$. radial longitudinally cut xylem ray crossing with fibre, fibre tracheids and ray cells embedded with starch grains and prismatic crystals of calcium oxalate; $\mathbf{1}$. prismatic crystals of calcium oxalate; $\mathbf{m}$. tailed, simple perforated, pitted vessels; $\mathbf{n}$. starch grains.

indicus collected from Maharashtra, physicochemical parameters have been compared (53) and the microscopic and chromatographic studies (hand TLC) has been reported (54).

\section{Phytochemical Screening}

$D$. hamiltonii and $H$. indicus root powders were subjected to phytochemical screening and their 


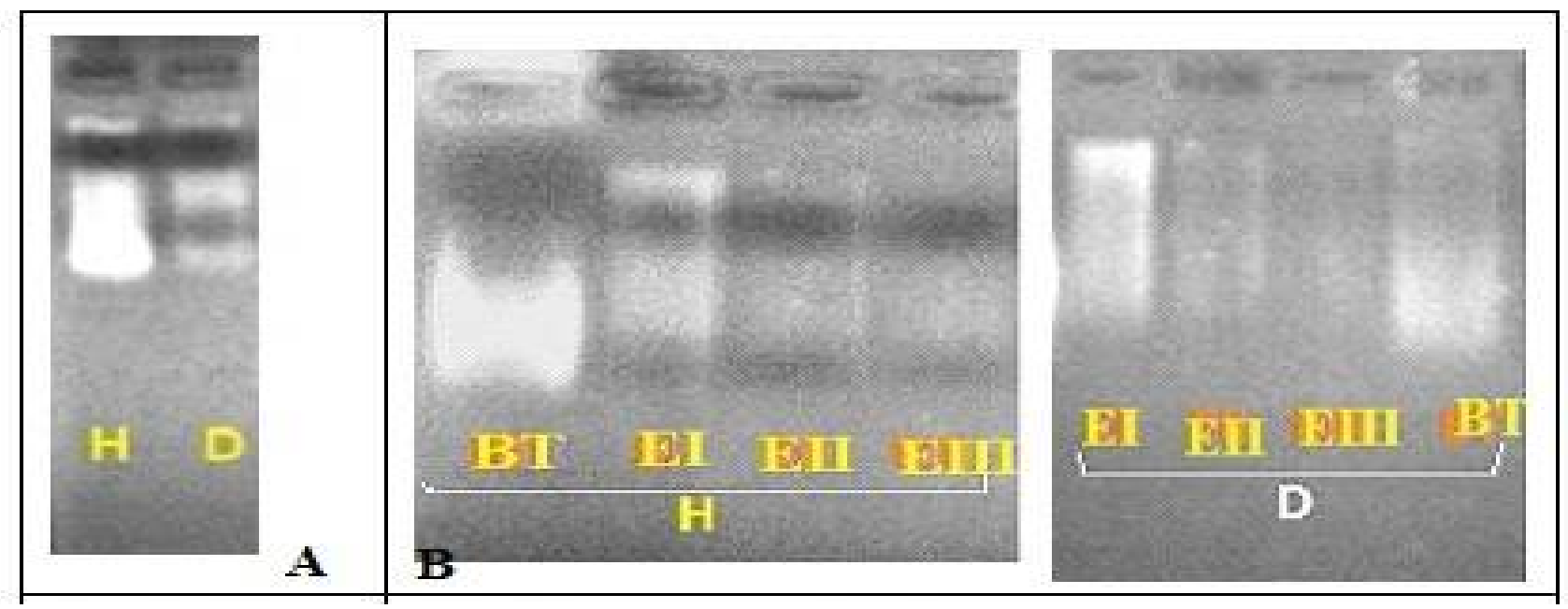

Fig. 5. A. Isolated DNA; B.Column purified DNA. H: H. indicus, D: D. hamiltonii, BT: Break through, EI: Elution I, EII: Elution II, EIII: Elution III.
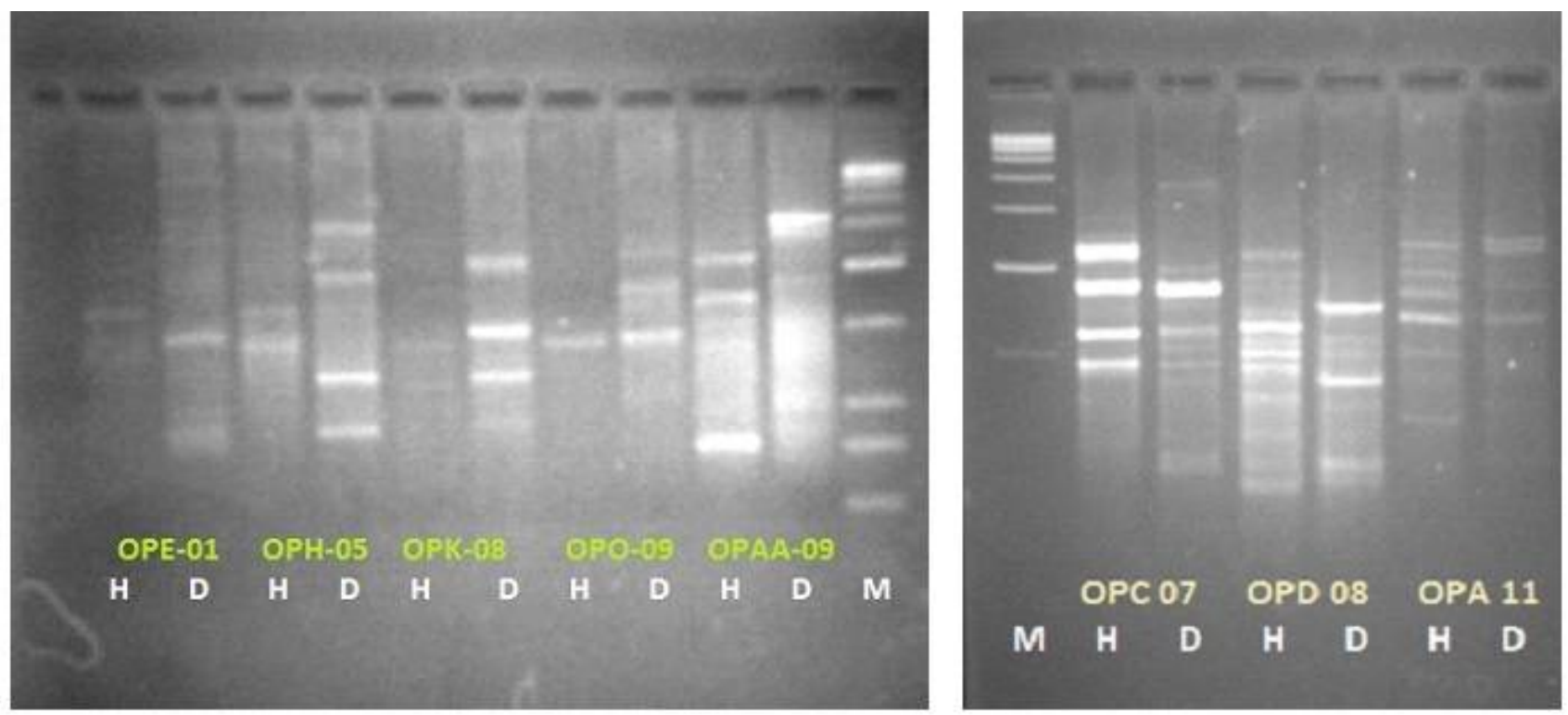

Fig. 6. Banding pattern of genomic DNA with random primers. H: H. indicus, D: D. hamiltonii, M: Marker.

presence, absence were documented (Supplementary Table 3). Tannins, flavonoids, steroids and coumarins were present only in $H$. indicus and absent in $D$. hamiltonii.

\section{TLC Photo Documentation/HPTLC Chromato- graphic Studies}

The TLC of all the extracts are shown in Fig. 7 and Supplementary Table 4 . In the TLC of hexane extract, under $254 \mathrm{~nm}$, a spot at $\mathrm{R}_{\mathrm{f}} 0.78$ appears in $D$. hamiltonii and absent in $H$. indicus; but under $366 \mathrm{~nm}$ no distinct spot appears; after derivatization a spot at $\mathrm{R}_{\mathrm{f}} 0.88$ (brown) appears only in $H$. indicus and not in D. hamiltonii.

In the TLC of chloroform extract, under $254 \mathrm{~nm}$, two spots at $\mathrm{R}_{\mathrm{f}} 0.19$ and 0.33 appears only in $D$. hamiltonii whereas two spots at $\mathrm{R}_{\mathrm{f}} 0.28$ and 0.81 (all green) appear only in $H$. indicus; under $366 \mathrm{~nm}$ six additional spots at $\mathrm{R}_{\mathrm{f}} 0.28$ (blue), 0.33 (ash), 0.36 (brown), 0.39 (ash), 0.52 (blue) and 0.61 (light green) appear in $D$. hamiltonii which are missing in $H$. indicus; after dipping in VSR two spots at $\mathrm{R}_{\mathrm{f}} 0.20$ (pink) and 0.45 (blue) appear in D. hamiltonii which are absent in $H$. indicus but one extra brown spot at $\mathrm{R}_{\mathrm{f}} 0.81$ appear.

In the ethanol extract, under UV $254 \mathrm{~nm}$, three spots at $\mathrm{R}_{\mathrm{f}}$ 0.33, 0.43 and 0.82 (all green) appear in $D$. hamiltonii which are missing in $H$. indicus; under UV $366 \mathrm{~nm}$, seven spots at $\mathrm{R}_{\mathrm{f}} 0.07$ (ash), 0.16 (blue), 0.18 (blue), 0.47, 0.52, 0.56 (all ash) and 0.70 (sky blue) appears only in $D$. hamiltonii but not in $H$. indicus; in the derivatized TLC of ethanol extract of $D$. hamiltonii spots at $R_{\mathrm{f}} 0.19,0.35$ (both violet) and 0.59 (yellow) appear whereas in $H$. indicus, a light pink spot at $\mathrm{R}_{\mathrm{f}}$ 0.55 appear. In the comparative TLC of both species, appearance of the above mentioned additional spots may be considered as distinguishing spots to identify the authentic $H$. indicus from the adulterated $D$. hamiltonii.

Under UV $254 \mathrm{~nm}$, the HPTLC of hexane extract of $D$. hamiltonii (Supplementary Fig. 4) showed major peaks (5, 7 and 8) at $\mathrm{R}_{\mathrm{f}} 0.32$ (area 22.47\%), 0.75 (27.05\%) and 0.85 (19.35\%); H. indicus showed major peaks (5, 8 and 9) at $\mathrm{R}_{\mathrm{f}} 0.33$ (13.38\%), $0.76(13.15 \%)$ and 0.88 (53.83\%); under $366 \mathrm{~nm} D$. hamiltonii 


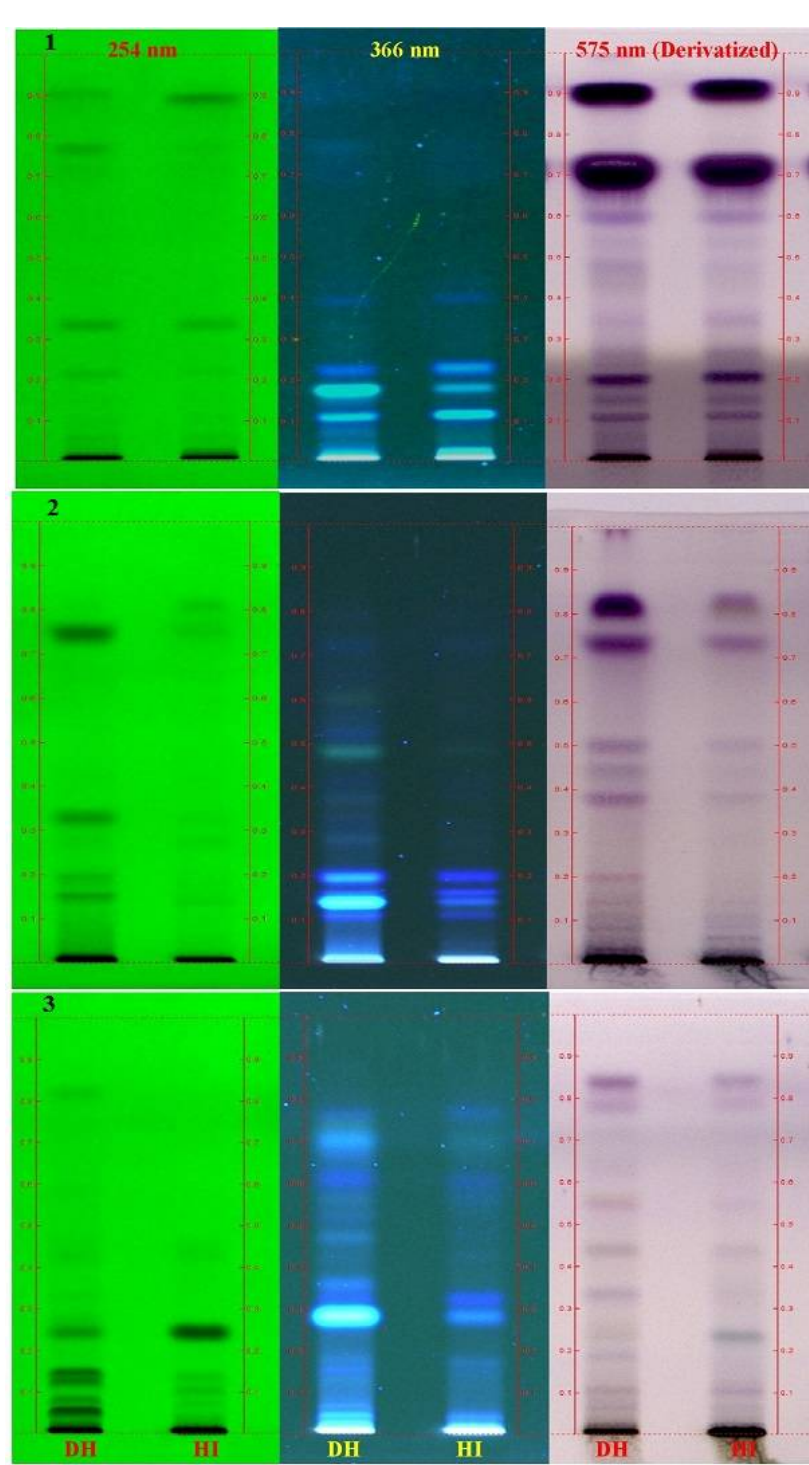

Fig. 7. TLC profile of $D$. hamiltonii and $H$. indicus root. 1. Hexane extract; 2 . Chloroform extract; 3 . Ethanol extract.

showed major peaks (2, 3 and 4) at $\mathrm{R}_{\mathrm{f}} 0.09$ (30.72\%), $0.15(56.94 \%)$ and $0.20(10.86 \%) ; H$. indicus showed major peaks (2, 4 and 6 ) at $\mathrm{R}_{\mathrm{f}} 0.09$ (46.27\%), 0.21 (19.86\%) and $0.90 \quad(20.97 \%)$; under after derivatization with VSR, at $520 \mathrm{~nm}$, for $D$. hamiltonii showed major peaks (10 and 12 ) at $\mathrm{R}_{\mathrm{f}} 0.68(31.67 \%)$ and 0.89 (28.75\%); $H$. indicus showed major peaks (3, 8 and 9 ) at $\mathrm{R}_{\mathrm{f}} 0.18$ (13.65\%), 0.69 (42.05\%) and 0.89 (28.14\%). The HPTLC finger print profile of $n$-hexane extract of $D$. hamiltonii at $254 \mathrm{~nm}$ shows three additional peaks at $\mathrm{R}_{\mathrm{f}} 0.13$ (area 2.86\%), $\mathrm{R}_{\mathrm{f}} 0.65$ (19.35\%), $\mathrm{R}_{\mathrm{f}} 0.94$ (4.65\%) which are not present in $H$. indicus; at the same time, $H$. indicus shows a peak at $\mathrm{R}_{\mathrm{f}} 0.67(7.53 \%)$ which is not visible in $D$. hamiltonii; at $366 \mathrm{~nm}, D$. hamiltonii shows a peak at $\mathrm{R}_{\mathrm{f}} 0.05(48 \%)$ but it is absent in $H$. indicus; $H$. indicus shows additional peaks at $\mathrm{R}_{\mathrm{f}} 0.43(1.98 \%)$ and $0.90(20.97 \%)$ than $D$. hamiltonii; at $520 \mathrm{~nm} D$. hamiltonii shows three extra peaks at $\mathrm{R}_{\mathrm{f}} 0.04,0.21$ and 0.72 which are not found in $H$. indicus.

Under UV $254 \mathrm{~nm}$, the HPTLC of chloroform extract of $D$. hamiltonii (Supplementary Fig. 5) showed major peaks (5 and 10) appeared at $\mathrm{R}_{\mathrm{f}} 0.31$ (area $13.51 \%)$ and $0.73(43.35 \%)$; for $H$. indicus showed major peaks (3, 9 and 10) at $\mathrm{R}_{\mathrm{f}} 0.25$ (11.30\%),
0.74 (26.41\%) and 0.79 (30.90\%); under $366 \mathrm{~nm}, D$. hamiltonii showed major peaks (1 and 2) at $\mathrm{R}_{\mathrm{f}} 0.11$ (64.97\%) and 0.17 (25.05\%); H. indicus showed major peaks (1, 2 and 3) at $\mathrm{R}_{\mathrm{f}} 0.11$ (18.52\%), $0.14(32.66 \%)$ and 0.17 (45.88\%); after derivatization with VSR, at $520 \mathrm{~nm}, D$. hamiltonii showed major peaks (11 and 12) at $\mathrm{R}_{\mathrm{f}} 0.71(34.76 \%)$ and 0.79 (35.39\%); H. indicus showed major peaks (9 and 10) at $\mathrm{R}_{\mathrm{f}} 0.71(42.50 \%)$ and 0.80 (37.84\%). The HPTLC finger print profile of chloroform extract of $D$. hamiltonii, at $254 \mathrm{~nm}$, shows peaks at $\mathrm{R}_{\mathrm{f}} 0.06(1.05 \%)$ and $0.53(6.06 \%)$ but they are not shown in $H$. indicus; and $H$. indicus shows additional peaks at $\mathrm{R}_{\mathrm{f}} 0.44$ (4.26\%) and 0.79 (30.90\%); at $366 \mathrm{~nm}, D$. hamiltonii shows four extra peaks at $\mathrm{R}_{\mathrm{f}}$ 0.26 (1.12\%), 0.46 (4.47\%), $0.50(2.27 \%)$ and 0.70 (2.10\%) but are not noted in $H$. indicus; and $H$. indicus shows a peak at $\mathrm{R}_{\mathrm{f}} 0.14$ (area $32.66 \%$ ) but it is not visible in $D$. hamiltonii; at $520 \mathrm{~nm}, D$. hamiltonii shows three peaks at $\mathrm{R}_{\mathrm{f}} 0.17$ (2.35\%), 0.25 (0.46\%), 0.29 (1.47\%) which are missing in $H$. indicus; while $H$. indicus shows two peaks at $\mathrm{R}_{\mathrm{f}} 0.04(0.85 \%)$ and 0.89 (3.73\%) but are not visible in $D$. hamiltonii.

The HPTLC of successive ethanol extract of $D$. hamiltonii, under UV $254 \mathrm{~nm}$ (Supplementary Fig. 6), showed major peaks (1, 3, 4, 5 and 10) appeared at $\mathrm{R}_{\mathrm{f}}$ 0.04 (area 13.78\%), 0.11 (12.58\%), 0.13 (14.70\%), 0.22 (24.56\%) and 0.79 (11.67\%); H. indicus showed major peaks (5, 7 and 9) at $\mathrm{R}_{\mathrm{f}} 0.24$ (46.88\%), $0.43(10.79 \%)$ and 0.75 (28.95\%); under $366 \mathrm{~nm}, D$. hamiltonii showed major peaks (2 and 7) at $\mathrm{R}_{\mathrm{f}} 0.25$ (75.96\%) and 0.67 (14.29\%); $H$. indicus showed major peaks $(2,3,5$ and 6$)$ at $\mathrm{R}_{\mathrm{f}} 0.28(30.79 \%), 0.33(17.11 \%), 0.76(14.71 \%)$ and 0.90 (21.02\%); after derivatization with VSR, at $520 \mathrm{~nm}$, D. hamiltonii showed major peaks (8, 9, 10, 11 and 12) at $\mathrm{R}_{\mathrm{f}} 0.54$ (15.82\%), 0.63 (10.26\%), 0.72 (10.41\%), 0.79 (16.58\%) and 0.84 (24.75\%); H. indicus showed major peaks (6, 7 and 8 ) at $\mathrm{R}_{\mathrm{f}} 0.72(21.62 \%)$, $0.80(17.31 \%)$ and $0.85(25.08 \%)$. The HPTLC finger print profile of ethanol extract of $D$. hamiltonii, at 254 nm, shows a peak at $R_{\mathrm{f}} 0.69$ (4.69\%) but it is not seen in $H$. indicus; at $366 \mathrm{~nm}, D$. hamiltonii shows four peaks at $\mathrm{R}_{\mathrm{f}} 0.41$ (0.60\%), 0.44 (1.49\%), 0.51 (0.78\%), $0.67(14.29 \%) \%$ ) which are not seen in $H$. indicus; whereas $H$. indicus shows a peak at $\mathrm{R}_{\mathrm{f}} 0.90(21.02 \%)$ but it is not visible in $D$. hamiltonii; at $520 \mathrm{~nm}, D$. hamiltonii shows four additional peaks at $\mathrm{R}_{\mathrm{f}} 0.04$ (0.85\%), 0.06 (1.01\%), 0.16 (1.57\%), 0.63 (10.26\%) which are not visible in $H$. indicus; but $H$. indicus showed a peak at $\mathrm{R}_{\mathrm{f}} 0.95(1.43 \%)$ but it is missing in $D$. hamiltonii. The presence or absence of distinguishing peaks may be useful for the authentication of warranted drug (55-56).

\section{Conclusion}

The present study that both roots shows differences size and shape of the cork cells, fibre, fibre tracheids, vessels, xylem parenchyma cells, polymorphism in eight primers, water and hexane soluble extractives, tannins, flavonoids, steroids, coumarins, difference in TLC spot in the ethanol 
extract which can be used for the identification of plant of interest and differentiate the authentic plant root from the adulterant available in crude drug market.

\section{Acknowledgements}

Authors are thankful to The Director General, Central Council for Research in Siddha, The Assistant Director I/c, Siddha Central Research Institute, SRM Institute of Science and Technology, Kattankulathur, Chennai and The Director, Aristogene Biosciences Pvt. Ltd., Bangalore.

\section{Authors' contributions}

ST performed the analytical studies and literature study, SS and KNS carried out the macroscopic, microscopical, powder microscopical studies, RP helped in data acquisition in RAPD, RS and GP designed the topic, edited and revised the manuscript with valuable suggestions.

\section{Conflict of interests}

Authors do not have any conflict of interests to declare.

\section{Supplementary files}

Table 1. Macroscopic characters of D. hamiltonii and $H$. indicus

Table 2. Details of polymorphism found in $H$. indicus and $D$. hamiltonii

Table 3. Phytochemical screening of $D$. hamiltonii and $H$. indicus root

Table 4. $\mathrm{R}_{\mathrm{f}}$ values and color spots of $D$. hamiltonii and H. indicus root

Fig. 1. Photograph of D. hamiltonii Wight \& Arn. A. Dried roots, B. Powder

Fig. 2. Photograph of $H$. indicus (L.) R. Br. ex Schult. A. Dried roots, B. Powder

Fig. 3. Physicochemical constants of $D$. hamiltonii and $H$. indicus root

Fig. 4. HPTLC 3D chromatogram and peak table of hexane extracts

Fig. 5. HPTLC 3D chromatogram and peak table of chloroform extracts

Fig. 6. HPTLC 3D chromatogram and peak table of ethanol extracts

\section{References}

1. Sujith T, Shakila R, Achintya KM, Divya KG, Mahesh F, Sunil kumar $\mathrm{KN}$ et al. Powder microscopic, physicochemical, HPTLC and antioxidant studies on noccik Kudinir chooranam - A polyherbal siddha formulation. J Young Pharm. 2019;11(4):371-76. https://doi.org/10.5530/jyp.2019.11.76

2. Welz AN, Emberger-Klein A, Menrad K. Why people use herbal medicine: insights from a focus-group study in Germany. BMC
Complement Altern Med. 2018;18:92. https://doi.org/ 10.1186/s12906-018-2160-6

3. Das M, Banerjii A, Dutta S, Saha S, Mondal DN, Hazra J. Phytopharmacognostical evaluation and HPTLC study on anantamul (Hemidesmus indicus R. Br.) root. Int J Res Ayurveda Pharm. 2017;8(3):68-72. https://doi.org/10.7897/2277-4343.083146

4. Raju AJ, Ramana KV. Traditional preparation of a health drink Nannari Sharbat from the root extract of Decalepis hamiltonii Wight \& Arn. Indian J Nat Prod Resour. 2011;2:121-24. http://nopr.niscair.res.in/bitstream/123456789/11551/1/IJNPR \%202\%281\%29\%20121-124.pdf

5. Samapika N, Anuradha M, Devendra Kumar P, Puja, Abhijit D. Indian Sarsaparilla (Hemidesmus indicus): Recent progress in research on ethnobotany, phytochemistry and pharmacology. $\begin{array}{lll}\text { Ethnopharmacol. } & \text { 2020;254:1-37. } & \text { https://doi.org/ }\end{array}$ 10.1016/j.jep.2020.112609

6. Anonymous. The Siddha Formulary of India. Part I, (1st edition) Ministry of Health and Family Welfare, Department of Health, Government of India, New Delhi, 1979; p.186.

7. Anonymous. The Siddha Formulary of India. Part II, (1st edition) (Tamil version), Ministry of Health and Family Welfare, Government of India, New Delhi. 1983; p.302.

8. Anonymous. The Ayurvedic Pharmacopeia of India. Part I, Vol 1, Ministry of Health and Family Welfare, Government of India, New Delhi. 2001; p.145.

9. Pudutha A, Venkatesh K, Chakrapani P, Singh CSB, Kumar P, Roja Rani A. Traditional uses, phytochemistry and pharmacology of an endangered plant Decalepis hamiltonii Wight and Arn. Int J Pharm Sci Rev Res. 2014;24(1):268-78.

10. Bhujbal SS, Dinesh K, Deoda RS, Deore TK, Patil MJ. Anti-asthmatic activity of roots of Hemidesmus indicus R. Br. Pharmacologyonline. 2009;1:209-16. https://doi.org/10.1016/S1995-7645(12)60011-X

11. Gadge NB, Jalalpure SS. Natriuretic and saluretic effects of Hemidesmus indicus R. Br. root extracts in rats. Indian J Pharmacol. 2011;43(6):714-17. https://doi.org/10.4103/0253-7613.89833

12. Kaur A, Singh S, Shirwaikar A, Setty M. Effect of ethanolic extract of Hemidesmus indicus roots on cisplatin induced nephrotoxicity in rats. J Pharm Res. 2011;4(8):2523-25. http://jprsolutions.info/newfiles/journal-file56f0b3c2ebf215.15122608.pdf

13. Shete RV, Bodhankar SL. Neuropharmacology of ethanolic extract of Hemidesmus indicus. Electronic J Pharmacol Ther. 2009;2:63-70. http://www.tcrjournals.com/ uploads/6121913. Shete.pdf

14. Sengupta M, Ghosh AK, Dalal I, Paul S. Anti-inflammatory activity of root of Decalepis hamiltonii, J Drug Delivery Ther. 2013;3(1):7073. https://doi.org/10.22270/jddt.v3i1.379

15. Srivastava A, Shivanandappa T. Neuroprotective effect of Decalepis hamiltonii roots against ethanol-induced oxidative stress. Food Chem.

https://doi.org/10.1016/j.foodchem.2009.07.003

16. Srivastava A, Shivanandappa T. Hepatoprotective effect of the root extract of Decalepis hamiltonii against carbon tetrachlorideinduced oxidative stress in rats. Food Chem. 2009;118:411-17. https://doi.org/10.1016/j.foodchem.2009.05.014

17. Nagarajan S, Rao LJ. Determination of 2-hydroxy-4methoxybenzaldehyde in Roots of Decalepis hamiltonii (Wight \& Arn.) and Hemidesmus indicus R. Br. J AOAC Int. 2003; 86(3):564-67. https://doi.org/10.1093/jaoac/86.3.564

18. Chatterjee RC, Bhattacharya BK. A note on the isolation of $\beta$ sitoserol from Hemidesmus indicus. J Indian Chem Soc. 1995;32:485 86.

19. Padhy SN, Mahato SB, Dutta NL. Triterpenoids from the roots of Hemidesmus indicus. Phytochemistry. 1973;12(1):217-18. https://doi.org/10.1016/S0031-9422(00)84656-7

20. Nagarajan S, Jagan Mohan Rao L. Triterpenoids from swallow roots - a convenient HPLC method for separation. J Chromatogr Sci. 2007;45(4):189-94. https://doi.org/10.1093/ chromsci/45.4.189

21. Mandal S, Das PC, Joshi PC, Das A, Chatterjee A. Hemidesmine, a new coumarino-lignoid from Hemidesmus indicus R. Br. Indian J Chem. 1991;30:712-13.

22. Das PC, Joshi PC, Mandal S, Das A, Chatterjee A. New coumarinolignoids from Hemidesmus indicus R. Br. Indian J Chem. 1992;31:342-45. 
23. Dutta AT, Ghosh S, Chopra RN. Chemische Untersuchung der Wurzeln von Hemidesmus Indicus I. Teil. Arch Pharm.1938;276:33340. https://doi.org/10.1002/ardp.19382760602

24. Srivastava A, Harish RS, Shivanandappa T. Novel antioxidant compounds from the aqueous extract of the roots of Decalepis hamiltonii Wight \& Arn. and their inhibitory effect on low-density lipoprotein oxidation. J Agric Food Chem. 2006;54:790-95. https://doi.org/10.1021/jf052433x

25. Posadzki P, Watson L, Ernst E. Contamination and adulteration of herbal medicinal products (HMPs): An overview of systematic reviews. Eur J Clin Pharmacol. 2012;69(3):295-307. https://doi.org/ 10.1007/s00228-012-1353-Z

26. World Health Organization. Reports on the global surveillance and monitoring system for substandard and falsified medical products and the public health and socioeconomic impact of substandard and falsified medical product. 2017. https://www.who.int/medicines/regulation/ssffc/publications/gsms-report-sf/en/

27. Parasuraman S, Thing GS, Dhanaraj SA. Polyherbal formulation: Concept of ayurveda. Pharmacogn Rev 2014;8:73-80. https://doi.org/ 10.4103/0973-7847.134229

28. Sahoo N, Manchikanti P. Herbal Drug Regulation and Commercialization: An Indian Industry Perspective. J Altern Complement Med. 2013;19(12): 957-63. https://doi.org/10.1089/acm.2012.0275

29. Notification GSR No. 893(E) of 170 guidelines for evaluation of Ayurvedic. Siddha and Unani Drugs. 2008. http://indianmedicine.nic.in/writereaddata/linkimages/4782799645-gaur.pdf

30. Agarwal P, Goyal A. A comprehensive review on adulteration and substitution of crude drugs. Asian J Pharmaceut Clin Res. 2021;14(4):33-38, https://doi.org/10.22159/ajpcr.2021.v14i4.40452

31. Srirama R, Santhosh Kumar JU, Seethapathy GS, Newmaster SG, Ragupathy S, Ganeshaiah KN, Uma Shaanker R, Ravikanth G. Species adulteration in the herbal trade: causes, consequences and mitigation. Drug Saf. 2017;40:651-61. https://doi.org/10.1007/s40264-017-0527-0

32. Liu Y, Lu F. Adulterated pharmaceutical chemicals in botanical dietary supplements: novel screening approaches. Rev Anal Chem. 2017; 36(3): 20160032. https://doi.org/10.1515/revac-2016-0032

33. Parani M, Anand A, Parida A. Application of RAPD fingerprinting in selection of micropropogated plants of Piper longum for conservation. Curr Sci. 1997; 73(1):81-83. https://www.jstor.org/stable/ 24098152

34. Matharu GK, Thappa D, Kamble V, Krishnan A, Sane RT. Use of genetic and protein markers for characterization of medicinal ayurvedic plants. Int J Pharmaceut Sci Res. 2010;1(12):95-110. http:// dx.doi.org/10.13040/IJPSR.0975-8232.1(12).95-10

35. Lizawati, Nusifera S, Neliyati, Alia Y, Antony. RAPD-PCR primer selection to analyze genetic diversity of Cinnamon plant. IOP Conf. Series: Earth and Environmental Science. 2019;391:1-7. https://doi.org/10.1088/1755-1315/391/1/012002

36. Anonymous. The Ayurvedic Pharmacopeia of India. Part I, Vol 1, Ministry of Health and Family Welfare, Government of India, New Delhi. 2001; pp.145.

37. Anonymous. Quality Control Methods for Medicinal Plant Materials, World Health Organisation, Geneva. 1998; pp.10-11.

38. Anonymous. The Ayurvedic Pharmacopoeia of India. Part-I, Vol.VI, First Edition. Ministry of Health and Family welfare, Govt. of India Dept. of AYUSH. New Delhi. 2008; pp. 233-42.

39. Iyengar MA. Pharmacognosy of Powdered Crude Drugs, Manipal Power Press, Manipal. 1980.

40. Sass JE. Botanical Micro Technique. Oxford and IBH Publishing Co Calcutta. 1958

41. Dymock W, Warden CJH, Hooper D. A history of the principal drugs of vegetable origin met with in British India Republic. Pharmacographia Indica, Vivek Vihar, Delhi, India, Vol. I, 1995;pp.68-69.

42. Maguire TL, Collins GG, Sedgley M. A modified CTAB DNA extraction procedure for plants belonging to the family proteaceae. $\begin{array}{llll}\text { Plant } & \text { Mol } & \text { Biol } & \text { Rep. }\end{array}$ https://doi.org/10.1007/BF02668371
43. Williams JGK, Kubelik AR, Livak KJ, Rafalski JA, Tingey SV. DNA polymorphisms amplified by arbitrary primers are useful as genetic markers. Nucleic Acids Res. 1990;18:6531-5. https://doi.org/10.1093/nar/18.22.6531

44. Collard BCY, Mackill DJ. Start codon targeted (SCoT) polymorphism a simple, novel DNA marker technique for generating genetargeted markers in plants. Plant Mol Biol Rep. 2009;27:86-93. https://doi.org/10.1007/s11105-008-0060-5

45. Sunil Kumar KN, Maruthi KR, Alfarhan AH, Rajakrishnan R, Thomas J. Molecular fingerprinting of Helicanthus elastica (Desr.) Danser growing on five different hosts by RAPD. Saudi J Biol Sci. 2016;23:335-40. https://doi.org/10.1016/j.sjbs.2015.12.002

46. Anonymous. Quality control methods for medicinal plant materials. World Health Organizing, Geneva. 1998.

47. Harborne JB. Method of extraction and isolation in phytochemical methods, (2nd edition), London Chapman and Hall, 1998; pp.60-66.

48. Raghunathan K, Roma M. Pharmacognosy of indigenous drugs. Vol. II, Sariva, Central council for research in Ayurveda and Siddha, New Delhi, 1982; pp. 897-904 and pp. 919-37.

49. Anonymous. Pharmacognosy of Ayurvedic Drugs of TravancoreCochin, Series-I, Central Research institute, Trivandrum. 1951; pp.14-20.

50. Anonymous. The Ayurvedic Pharmacopoeia of India. Part-I, Vol. I, $1^{\text {st }}$ edition, Government of India, Ministry of Health and Family welfare, Department of AYUSH, New Delhi, 1986; pp. 144-45.

51. Anonymous. Quality Standards of Indian Medicinal Plants. Vol-2, ICMR, New Delhi, 2005; pp.119-28.

52. Brindha S, Remya A, Divya KG, Rubeena M, Erni B, Murugammal S. Key distinguishing characters (KDCs) of official (Boerhaavia diffusa L.) and commonly mistaken (Trianthema portulacastrum L.) sources of Mukkirattai of Siddha. Plant Sci Today. 2020;7(3):391 403. https://doi.org/10.14719/pst.2020.7.3.792

53. Nandgaonkar PP, Khobragade P, Pargaonkar AS, Nandgaonkar PS Comparative organoleptic and physicochemical study of roots of Hemidesmus indicus (L.) R. Br. and Decalepis hamiltonii Wight \& Arn. J Indian Sys Medicine. 2019;7(2):93-98. https://doi.org/10.4103/JISM.JISM_44_19

54. Nayar RC, Pattan Shetty JK, Mary Z, Yoganarasimhan SN. Pharmacognostical studies on the root of Decalepis hamiltonii Wight and Arn. and comparison with Hemidesmus indicus (L). Proc Natl Acad Sci. USA,1978;87:37-48. https://www.ias.ac.in/article/fulltext/plnt/087/02/0037-0048

55. Saraswathy A, Shakila R, Sunil Kumar KN. HPTLC finger print profile of some Cinnamomum species. Pharmacogn J. 2010;2(7):21115. https://doi.org/10.1016/S0975-3575(10)80095-1

56. Saraswathy A, Meena AK, Shakila R, Sunil Kumar KN, Ariyanathan S. Pharmacognostic studies on Alangium salvifolium (Linn. f.) Wang root bark. Pharmacogn J. 2010;2(11):374-80. https://doi.org/10.1016/ S0975-3575(10)80018-5

Additional information

Peer review information: Plant Science Today thanks Sectional Editor and the other anonymous reviewers for their contribution to the peer review of this work.

Reprints and permissions information is available at

https://horizonepublishing.com/journals/index.php/PST/open_access_policy

Publisher's Note: Horizon e-Publishing Group remains neutral with regard to jurisdictional claims in published maps and institutional affiliations.

To cite this article: Sujith T, Susikumar S, Sunilkumar KN, Radha P, Shakila R, Gopinath P. Detection of adulteration of Decalepis hamiltonii Wight \& Arn. with Hemidesmus indicus (L.) R. Br. by pharmacognostic, molecular DNA fingerprinting by RAPD, chemical and HPTLC studies. Plant Science Today. 2021;8(3):610-620. https://doi.org/10.14719/pst.2021.8.3.1151

Plant Science Today, published by Horizon e-Publishing Group, is covered by Scopus, Web of Science, BIOSIS Previews, Clarivate Analytics, etc. See https://horizonepublishing.com/journals/index.php/PST/indexing_abstracting 